Farah / The Levantine Review Volume 2 Number 2 (Winter 2013)

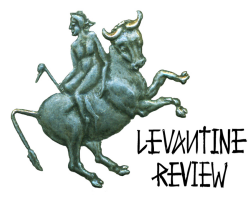

\title{
IDENTITY AND CULTURE OF ISRAELI CHRISTIANS IN THE FACE OF ISLAMIC RESURGENCE; CULTURAL DISTINCTIVENESS OF A MINORITY WITHIN A MINORITY
}

\author{
Rima Farah*
}

\begin{abstract}
This paper examines how Israeli Christians perceive their cultural position between Jewish and Muslim identities in Israel. The study primarily relates to the cultural differences between Christians and Muslims, and to the relations between them in mixed villages and towns. It focuses on how the sense of identity and the cultural aspects, combined with the rise of the Islamic identity and the change of Arab society's structure has affected the peaceful coexistence between Christians and Muslims. Lastly, the research addresses the 1999 Christian-Muslim riots (Shihab al-Din Events) in Nazareth over plans to construct a Mosque in front of the Church of Annunciation.
\end{abstract}

The genealogy of Israeli Christians and Muslims reveals the distinctive ethnic backgrounds from which they stem. Most families of the Upper Galilee, such as those in al-Jish, kfar Bir'im, Mi'ilia, Fasuta, Iqrith, Tarshiha, and al-Buqaia', originated mainly from Lebanon and Syria. Those who live in the lower Galilean regional cities and towns, such as Nazareth, alReina, Tur'an, and Kfar Kanna were originally Arab Christian tribes who came to Palestine from different territories along with some Syrian and Lebanese families. ${ }^{1}$ Given the distinct background of these families, according to Christian author Shukri Arraf of Mi'ilia:

The North [starting from Haifa and Tiberias] is influenced by the civilization of Bilad al-Sham (Greater Syria), the Syrian and the Lebanese, mainly the Lebanese, because Lebanon is Christian and had a great influence on us. The coastal plane is influenced by the Egyptian [civilization]: the road to Egypt was through Jaffa and Gaza. Today, most of the people in Gaza speak the

${ }^{1}$ For more information on the origin of the Christian families in Israel see Hussam Majahed 'Adawi and Jamal Nayef 'Adawi, Tur'an: Al-Tarikh wa al-Insan (Tur'an: The history and the Human Being), 1995, pp. 48-54. Min'im Hadad, Pqe'in: Agada, Hivuy ve-Masoret (alBuqaia': A Legend, Folklore and Tradition). Tel-Aviv: 'Am 'Oved, 1987, p. 26. Shukri Arraf and Rafiq Najar, Fasuta: Al-Tarikh wa-al-Insan (Fasuta: History and Human Beings). Tarshiha: Matba'at Ikhwan Makhul, 1993, pp. 55-65. Hussein Mansour and Johnny Mansour, Al-Reina: al-Tarikh, al-Thakira wa-al-Waqe' (Al-Reina: the History, Memory and Reality), 2007, pp. 83-191. Yousef 'Aref Mattar, Kfar Kanna, Qana al-Jalil, 'Abr al-'Ausur (Kfar Kanna, Qana of Galilee, throughout the Ages). Nazareth: Department of Arabic Education, Ministry of Education, Science and Sports, 2006, pp. 33-42. Amer Awawda, Kfar Kanna: Tarikh wa-Turath (Kfar Kanna:History and Tradition), n.p. 2008, pp. 54-86. 
Egyptian dialect and not ours. The rest of the mountain is influenced by

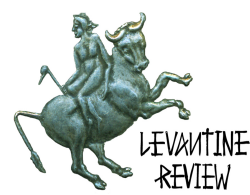
nomadism, Jordan and al-Naqab [the Negev]. Practically, we have four civilizations. ${ }^{2}$

The blending of generations of Christians through marriage and social ties masked the cultural differences between the genealogical civilizations, and formed an apparent unified Christian society of distinctive congregations. They coexist in Israel with the larger Muslim minority, with whom they share some common social practices; and with the Jewish majority with whom their social structure is similar.

Throughout Middle East history, religion has always been the major factor in defining cultural and social features of societies. Due to the decline of the vision of Arab nationalism and its failure to mold a single distinct "national character" through which all ethnic and religious groups would be defined, old and new cultural disparities between Christians and Muslims in Israel have begun resurfacing.

The strengthening Islamic religious identity and the change in the demographic balance between the Christian and Muslim communities in favor of the latter have changed the face of Israel's Arab-defined society. With the decline of Arab nationalism and the absence of a unifying national cause, religion and citizenship remain the major determining factors of social groups. However, since citizenship in a Jewish state is perceived as a challenging factor, religion remains the primary identity to which groups in Israel are affiliated.

Parallel to the Islamic awakening among Muslim Israelis, a partial 'Westernization' of Christian society took place as it gradually began to transform into a society with some western social characteristics. Thus, the cultural gap between the two communities widened as more Muslims adopted a religious and conservative lifestyle, in contrast to the many Christians who preserved their culture but also adopted many features of Western lifestyles. The growth in the social gap between the two communities redefined Christian social identity, which became culturally more segregated. Cultural differences were not merely a result of the Islamic revival; however, they became more obvious as religion gradually became a dominant criterion of identity among Muslim Israelis.

Culture is an important aspect of identity, providing the members of identity groups with common features such as language, symbols, rituals and customs, as well as distinctive lifestyles. These features form cultural identity groups, and can act like social glue that unites people. At the same time culture can divide people into conflicting groups, or into communities mixed with other groups. ${ }^{3}$ In the modern era, identity has been depicted as a possessed "entity," an essential core of the self who may be identified as the individual, the

2 Interview, August 28, 2010.

3 Amy Gutmann, Identity in Democracy. Princeton: Princeton University Press, 2003, pp. 3841. 
religious community, or the nation. Postmodern thought, by contrast, regards the self/other and its boundaries as culturally constructed and ever-changing by circumstances. The change of Christian social markers overtime became more evident after the new assertion of the Islamic identity among Israeli Muslims. Following the developing tensions between Christians and Muslims, which had reached their zenith in Nazareth in 1999 over the Shihab al-Din Mosque, the segregation between the two communities, intensified.

\section{INTEGRATION OR SEGREGATION? BETWEEN THE JEWISH AND MUSLIM MAJORITIES}

Coexisting in Israel with the majority Jewish population and the increasingly religious and dominant Muslim minority, Israeli Christians have developed different approaches to their cultural position amidst these two groups. Some research and surveys show that despite living with Jews and Muslims, Christian Israelis are an identity group that preserves some distinctive cultural features. They share some cultural practices with the Jews and the Muslims, but they reject the process of assimilating into either of these groups. This is revealed in Horenczyk and Munayer's study about acculturation, in the survey about the Christian youth in the Galilee of al-Liqa' Center for Religious and Heritage Studies in the Holy Land, and in Rachel Hertz-Lazarowitz research of the psychological aspects of life in the Haifa University campus.

Research about acculturation discusses "the interplay between the individual's attachment to his/her minority or original culture, and his/her attitude and involvement with the dominant culture." ${ }^{4}$ In Horenczyk and Munayer's study of the attitudes of 281 Christian adolescents (from 12 to 18 years old) to the cultures of the other two groups there is an emphasis on the acculturation attitude of the Christians towards each group:

Assimilation was the least endorsed attitude with regard to both Arab Muslims and Jews. However, respondents expressed more willingness to adopt elements of Jewish society than Muslim Arab society. Integration was the strongest attitude with regard to Israeli Jews, whereas separation ranked first when asked about Muslim Arabs. ${ }^{5}$

The willingness of Christians to integrate into Jewish society has a twofold interpretation. The first is their wish to gain better access to the major resources of the country, dominated by the Jewish group. The second is their wish to be closer to the Western secular Jewish group with which they share some social characteristics that the Muslims

${ }^{4}$ Gabriel Horenczyk and Salim J. Munayer, "Acculturation Orientations toward Two Majority Groups: The Case of Palestinian Arab Christian Adolescents in Israel", CrossCultural Psychology, vol. 38 (2007), p. 76.

5 Ibid., p. 83. 
lack. The 2000 research findings of Munayer indicate that Israeli Christians perceive the state as highly Westernized, and therefore, preferred over Muslim culture. ${ }^{6}$

Horenczyk and Munayer relate to George Sabra's study of Christians in the Middle East. Sabra divides Christians in the Middle East into two groups. One is "Arab Christians" who identify with the dominant Muslim culture and the Arab identity as it exhibits an aversion to the West, Israel, and the Western culture. The other is "Eastern Christians" whose primary concern is safeguarding Christians in the Middle East in the face of the threat that Islam poses to their existence. ${ }^{7}$ Horenczyk and Munayer's research shows that Israeli Christians tend more toward the "Eastern Christian" position (Using Sabra's conceptualization and terminology) than to the "Arab Christian" one. ${ }^{8}$

The survey findings al-Liqa' center ${ }^{9}$ for Religious and Heritage Studies in the Holy Land show that $86 \%$ of the respondents believe that the relationship between Christians, Muslims, and Druze has deteriorated in the last 5 decades. However, about $43 \%$ believe that it is good, $41 \%$ say it is "in between," and only $13 \%$ describe it as critical or deteriorating. Furthermore, about $60 \%$ of the participants in the survey believe that as minorities, Christians and Muslims share the same destiny, and 80\% indicate that the Jewish character of the state is problematic as it denies them full integration in Israeli public life, and $55 \%$ fear for their future because they belong to a religious minority. ${ }^{10}$ While $51 \%$ believe that the general relations between the Christians and the Jews are excellent or good, and $63 \%$ describe it as positive, fewer than half of the participants (41\%) have social ties with Jewish friends. A majority of $87 \%$ has no personal Jewish friends. ${ }^{11}$ These findings show that despite living between the Jewish and Muslim groups, Christians preserve their in-group identity.

In her work on the psychological aspects of life in the Haifa University campus, Rachel Hertz-Lazarowitz studies the differences between the Jewish, Muslim, Christian and Druze feeling of anxiety before and after the second war with Lebanon (2006-2007). Asked about

${ }^{6}$ Ibid., p. 84.

${ }^{7}$ George Sabra, "Two Ways of being a Christian in the Muslim Context of the Middle East", Islam and Christian-Muslim Relations, 17 (2006), pp. 43-53.

8 Gabriel Horenczyk and Salim J. Munayer, "Acculturation Orientations toward Two Majority Groups: The Case of Palestinian Arab Christian Adolescents in Israel", p. 84.

9 For more findings of al-Liqa' survey about the identity of Christian youth in Israel see Rima Farah, "Identity and Culture of Israeli Christians in the Face of Islamic Resurgence." Unpublished Thesis. University of Haifa: Department of Middle Eastern Studies, 2012m p. 83.

${ }^{10}$ Bernard Sabella and Jeris Khoury, "al-Shabab al-Masihi fi al-Jalil: Hawiyyah Tufatish 'an Istiqrar" (The Christian Youth in the Galilee: an Identity in Search of Stability), in al-Liqa', vol. 3-4, 2011, pp. 62-63, and p. 108.

11 Ibid., pp. 109-110, and p. 66. 


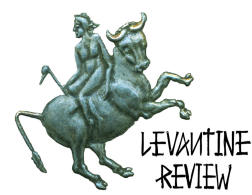

the impact of the war, the Christian interviewee said: "It has great impact on many things. The Jews initiate a war, the Muslims want a war, and we are stuck in between. We want to live, both Jewish and Muslims, let us live."12 Following the war, the anxiety among Christians and Jews was found to be higher than it is among Muslims and Druze. It is higher among the Jews who are a regional minority numerically dominated by a Muslim majority, and among Christians who are a minority within a minority in a Jewish state. According to Hertz-Lazarowitz, being a double minority in Israel, and despite their identification with the Muslims in Lebanon during the war, Christians perceive themselves as "unrelated" to Muslims and Jews. ${ }^{13}$

\section{BETWEEN PURELY CHRISTIAN AND MIXIED VILLAGES AND TOWNS}

It would be difficult to find Arab villages and cities in Israel today that do not have some element of the Christian-Muslim amalgam, whether in terms of place of residence, employment or commerce. There is a visible social gap between the two communities measured by demographic and cultural features. The cultural gap between Christians and Muslims is readily noticeable when comparing the lifestyle of Christians in pure Christian villages with that of Muslims in Muslim villages and towns. The gap narrows in mixed villages and towns, and is measured by the demographic balance between the two groups.

There is little or no interaction between Muslim kids from the small Triangle like Umm alFahm, Baqa al-Gharbiyya, and Kfar Qara' where the population is purely Muslim, and Christian kids from other mixed or Christian villages and towns. The clear-cut social segregation between the two communities has widened further, and the mutual estrangement between them increased so that they are now "strangers". Israeli Christian author Salem Joubran (1941-2011) indicates that this isolation is increasing:

Today, the situation is deteriorating. I tell you, it is also very difficult. It is not a scientific case. When you go to the small Triangle to give a lecture, you speak Arabic better than them, and you speak about Arab Nationalism better than them, and at the end someone would come aside and say: "Mr. Salem, Salem Joubran, a Christian, right?!!!".14

Or, as Muwafaq Khoury from 'Ibilin village, who was recently deputy director in the ministry of Culture and Sport, responds to the reaction of some Muslims in the Triangle in regards to Christian women guides that he sends to their schools:

12 Rachel Hertz-Lazarowitz, "Hebetim Psikhologiyyim shel ha-haim ba-kampus ha-heifaee Lefnei ve Ahrei Milhemet Levanon Hashniyya" (Psychological Aspects of Life in Haifa Campus before and after the Second War of Lebanon), paper submitted to I'yonim be Minhal u-be-Irgun ha-Hinukh (September, 2007), p. 19.

13 Ibid., p. 20.

14 Interview, August 25, 2010. 
Young women guides wearing a cross enter the classes in schools in al-Taiba, al-Tira and in Umm al-Fahm, and believe me I receive a lot of phone calls:

"What is this, who is this, she is a Christian!!!," and the young women come to me and say "What shall we do?"15

The emphasized Islamic identity of the last three decades has changed the face of mixed villages and towns mainly where Muslims are a clear majority. The Islamic revival had little or no influence on Christian villages such as Mi'ilia and Fasuta, and in mixed villages where the size of the two communities is almost equal, as in al-Jish. However, in villages like Tarshiha, Kfar Yasif, Tur'an, al-Reina 'Ibilin, and in mixed towns like Nazareth and Shafa'amr where the size of the Muslim community has grown rapidly in the past few decades, the influence of the Islamic religious revival is more perceptible.

Israeli Christians identify with one another despite the admitted cultural differences among them. At times, they are differentiated by culture and sect, but they are united by distinctive features when compared to other groups. According to author Shukri Arraf of Mi'ilia:

Socially, many of our habits do not meet with other societies. I am talking about social habits. For example, the way we sit around tables in weddings. If you come to Mi'ilia you see women are "naked," in weddings women wear modern open dresses, because this is the urban, this is Paris, meaning we are Westernized. Or, better say, globalized... The church does not affect our lives and the clergy does not intervene with us. Jesus did not care for our bodies, but our souls. Therefore, our social practices are different. ${ }^{16}$

Mi'ilia's entertainment places developed socially in response to the Western lifestyle of the village's inhabitants who preserve local culture, but also adhere to Western lifestyle. The sparkling night life and the modern unconventional dress in Mi'ilia became major features that Christians from mixed villages and towns confirm cannot exist where they live. Muwafaq Khoury says:

There is no pressure imposed on the Christians in Mi'ilia, and religion offers them freedom. I didn't know about what I see of young boys and girls at night in the streets walking, we don't see this in my village because it is mixed, Muslims and Christians. ${ }^{17}$

Duaa Khoury, a 25 year old woman, an interior design student from Tarshiha, explains the difference between living in a Christian and a mixed neighborhood. According to Khoury,

15 Interview August 31, 2010.

16 Interview, August 28, 2010.

17 Interview, August 31, 2010. 


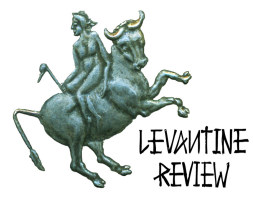

living in a Christian-Muslim village or neighborhood sometimes limits women's freedom of dress and movement. In order to avoid criticism, they are bound to observe certain dress and behavior codes:

When you live in a Christian neighborhood, you feel that people belong to each other and have the same habits. Meaning we are all of the same kind and have the same habits and the same way of thinking. You will feel freer. Among Muslims, my behavior should be different. I am more restricted in my activities. ${ }^{18}$

Khoury compares between Tarshiha and Mi'ilia high schools, where she studied. For her, studying in a purely Christian school and a mixed school with a Muslim majority are two distinctive experiences:

It is a [purely] Christian school. You can sit, speak and walk comfortably without being looked at strangely; no one will criticize you. I was very happy because no one would give me a bad and unpleasant look, unlike in Tarshiha... A pupil once was wearing a cross around his neck (in Tarshiha school) and the Christian manager, out of fear, asked the pupil to remove it, although many others [Muslims] wore a necklace with the Allah (God) or the Quran symbol. Let's say that it is a kind of fear. He would request that from Christian, but not from Muslim pupils. ${ }^{19}$

In 2003, when she was in the eleventh grade, Khoury moved to Mi'ilia School together with three successful Muslim students. As the only Muslim pupils in the school, they were perceived as "foreigners", and therefore they were incapable of adjusting to the school's social system. She further says:

These boys could not stay because the school's climate did not fit them. Neither the school nor the pupils allowed or opened the opportunity for them to continue. ${ }^{20}$

Mi'ilia's high school principal, Iyad Qassis, confirms that these Muslim pupils left soon because they felt like strangers, and could not integrate into the school's culture. They applied to Notre Dame School, but they left because they could not blend or adjust in the climate of the school. ${ }^{21}$

18 Interview, August 15, 2010.

19 Ibid., August 15, 2010.

20 Ibid., August 15, 2010.

21 Interview, September 18, 2010. 
Qassis talks about Notre Dame School's high educational achievements after the influx of local and neighboring Christian pupils who left Tarshiha School. Beginning in 2000, the educational level in Tarshiha, and other governmental schools in the region dropped. Christian families in Mi'ilia considered Notre Dame as an alternative school. He defines the Notre Dame School as a "unique model," the only Christian school in Israel that is not associated with or managed by a church. It is partially funded by the Ministry of Education and by German organizations who built the school. According to Qassis, the increased influence of the demographic change in Muslim society and the Islamization of the region brought with it a decline in the educational level of the governmental schools.

Elias Shahin, a former Tarshiha school principal (1975-2005), says that in 1985, there was a constant decline in the enrollment of the Christian pupil majority. At that time, Bedouin pupils of Ne'em, who had immigrated to Tarshiha along with Muslim pupils from nearby Mazra'aa village, joined the school. From 2000 to 2010, the percentage of the Christian pupils began to drop. These changes brought a significant decline in the school's achievement level as pupils from Mi'ilia, Fasuta, and Tarshiha left and went to Notre Dame School. The conditions changed in Tarshiha School, and Ort (a non-state-run network of schools in Israel) took control. ${ }^{22}$ Today, the major school to which many Christians from the surrounding villages send their kids to study is still Mi'ilia's.

In comparing life in a Muslim-Christian village like al-Reina, where Muslims form the majority, with life in Upper Nazareth city, where Christians live under a Jewish majority and a smaller minority of a Muslim community, one may find similar cultural tendencies. A 28 year old social worker, ${ }^{23}$ originally from al-Reina, talks about the conservative social life of those who live in al-Reina, where she moved from, as opposed to the social freedom of the Christian minority in her new neighborhood in Upper Nazareth:

My family who lives in a mixed neighborhood [in al-Reina] is more conservative and considerate to the traditions of the other religion, that is the Muslim... I would not dress up when I go to al-Reina the same as I would in my neighborhood [In Upper Nazareth], or in Haifa. I can wear a sleeveless top, but not shorts. I will not go down the street wearing a short dress. Today you may find Muslim women also wearing sleeveless tops and short skirts in some ceremonies, but when they see a woman who covers her head, they would tell her "yes, cover it; I am so happy for you. You are great!!!" making you feel that you have done something wrong [for not covering your head]. ${ }^{24}$

22 Interview, July 31, 2010

23 The interviewee requested to be anonymous.

24 Interview, September 15, 2010. 


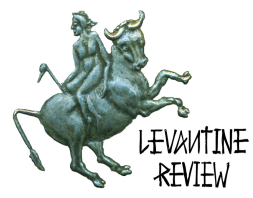

She further indicates that despite the fact that the more conservative older Christian and Muslim generations have lived together, today the cultural gap between the new generations of both communities has become more evident:

There is a great difference, their lifestyle is different. Their way of thinking is different, their weddings are different, their inclinations and even their vision of things is different. I realized and felt this more when I started working with Muslim and Christian families in the village. The two have different approaches and therefore cannot be treated similarly. ${ }^{25}$

For many decades there were good relations between Christians and Muslims in al-Jish. Author George Akel (1923-2012), Deacon Atanas' brother who had good relations with Israel's second president (Itzhak Ben Tzvi), received permission from the government of Israel to allow the population of al-Jish to stay after the 1948 war. Akel, who was also a classmate of the Maronite Cardinal Sfeir in Lebanon, talked about al-musayara (amity) between the two communities:

The Christians of al-Jish were musayeron (amicable) to Muslims when they were a majority and then a minority. Therefore, they [the Muslims] feel free among the Christians. They live in the eastern part of the village. Many tried to create disturbance, but no one [Christians or Muslims] opposed them. However, also when the Muslims were the majority [at the end of the British mandate, when many Christians immigrated to Haifa], they were also musayeron to the Christians. ${ }^{26}$

The majority of the Christians in al-Jish are Maronites. ${ }^{27}$ Akel regards many social habits of all Christians in al-Jish as distinctive from social habits in other villages and towns. According to him, the distinctive habits come from a long heritage, which his grandfathers brought with them when they came to the village:

We the Christians of al-Jish say that we are originally from Lebanon. The majority of our habits we brought with us from Rmeish and Ein Ebel, we received this information from our fathers and grandfathers who brought our culture from Lebanon... Every Balad [village or town] has its distinct habits, and so does al-Jish. We cannot say that al-Jish is like Tarshiha or

25 Ibid., September 15, 2010.

${ }^{26}$ Interview, 15 December, 2011.

27 For more information about the conflict over the Maronites' identity and their historical roots see Rima Farah, "Identity and Culture of Israeli Christians in the Face of Islamic Resurgence," pp. 94-108. 
Fasuta or Mi'ilia. Al-Jish has, independently from other villages, developed its own methods and landmarks, based on people's own experiences. ${ }^{28}$

According to Akel, cultural differences between Christians and Muslims are evident in weddings and in male-female relations. In his village, women and men meet, mingle, and dance together. This is unlikely in weddings in Muslim Umm al-Fahm, where in most occasions there is a separation between the sexes:

If we go to a wedding in Umm al-Fahm we will not find boys and girls dancing Dabki together. We are not pedantic as they are. Do we need to keep a young woman or my sister at home? I trust her. This is why we are different from them [The Muslims.] In their habits, they separate between the young men and women, but this is not our habit. 29

In Kfar Yasif, a demographically balanced Christian-Muslim village in the Upper Galilee, Christian lifestyle remains predominant. The 25-year-old Greek Orthodox Psychology student, Violet Khoury, grandchild of the ex-head council Violet Khoury, describes the widening cultural gap between the increasingly religious Muslims and the Westernizing Christians:

The more we progress, the more it becomes difficult for us to accept the Hijab [Veil]. Why? It's because of globalization. We are opening up to the West, and we see how everybody is dressed. So, our dress is changing accordingly. They [the Muslims] don't change. In the past, it was easier to accept the religious dress, there was more affinity among people, the village was smaller, and they trusted more one another when no political struggles influenced their opinions. With progress, we adopted Western customs, adhered to new habits and came to live differently. ${ }^{30}$

In her discussion of the cultural differences between Christians and Muslims in her village, Khoury comments on the nature of male and female relationships among Muslims as tense:

Their weddings and their taste are different. Among them, you can feel the tension in the relationship between the two sexes, or in the relations with the other sex. You would notice their lack of comfort. In the past they used to separate between men and women. Religious people still do so today. ${ }^{31}$

28 Interview, December 15, 2011.

${ }^{29}$ Ibid., December 15, 2011.

30 Interview, October 10, 2010

31 Ibid., October 10, 2010. 


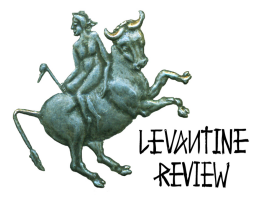

Christians are a minority in the Lower-Galilee mixed city of Shafa'amr. Lucia Lucian who is originally from the city, talks about the change in the relations and cultural differences between Christian and Muslim communities, which occurred in the past two decades. He discusses the social disparities between the two communities in male-female bonding, festive ceremonies like weddings, and religious practices. Lucian says that the cultural gap existed in the past, but the two communities were better able to coexist. In the last 20 years, the separation widened:

The differences exist in weddings, education, religion, in the extent of religiosity and secularism, and in perception of how much one can be secular in the different aspects of social life. I mean, the type of dress and the socialization between young men and women... In the past, there were more connections [between Christians and Muslims]. There were coexistence, mixing and harmony [between them.] Since the last 15 or 20 years, the situation changed. Coexistence and understanding exist between separated masses. Before that, there was one big common mass, but today separated communities exist. ${ }^{32}$

Lucian notes that a new group or class emerged in Shafa'mr, which he calls, the "fourth community." In this small community, more common denominators are found among Christians and Muslims who live a similar "secular" lifestyle in a mixed neighborhood:

There are obvious differences between the two communities. However, in the mixed neighborhood lives a class [of Christians and Muslims], with a similar lifestyle. In the past, when there were more connections [between Christians and Muslims,] they shared one common education system. A "fourth community" was born. The high education school was common to all communities. But, today, other high schools were established, and the Greek Catholic school became a high school leading Christians to leave the common school. ${ }^{33}$

He further adds that this community has always been a small minority and still is today. Its status, however, has been undermined in the last two decades due to the Islamic religious awakening:

In the last 15 or 20 years, the "fourth community" has shrunk as a result of the strong return to religion. People [Muslims] have returned to religion, and those who didn't, still couldn't advance in the secular approach. There are veiled women [in Shafa'amr.] However, their percentage is less than it is in other places... The "fourth community" is facing fear and restrictions from

32 Interview, January 12, 2012.

33 Ibid., January 12, 2012. 
society. On a personal level, many [Muslims in Shafa'amr] wish to adopt the

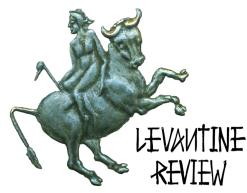
secular and liberal thought, but they fear society. ${ }^{34}$

In his 1989 study, Chad Emmett conducted interviews with citizens of both communities on a range of topics about the complex Christian-Muslim relations in Nazareth. According to one of the Emmett's Christian interviewees, Christians and Muslims in Nazareth shared a "common culture." The shared interpersonal relationships and experiences include participation in weddings, celebrations, hospitality, brotherhood, friendship, as well as integration in education and service, the market and workplaces, and most of all by being a minority in a Jewish state. ${ }^{35}$

Some interviewees rejected identifying individuals by religion, claiming that they are all Arabs. ${ }^{36}$ When asked questions like: "what religion is someone affiliated with," and "if the neighborhood was Christian or Muslim," the responses were "just Arab," "why ask about religion?" "we are all Arabs," or "neither Christian nor Muslim, but Arab."37 Emmett finds that Muslims are more optimistic than Christians about the relations between the two communities, and that among Christians, the Greek Orthodox are more in favor of Christian-Muslim relations than Roman Catholics. ${ }^{38}$ He also relates to the rift between the Maronites and the Muslims then. The Maronites did not participate in the march of 'Id al- $a$ Adha and in Ramadan dinner like others do. The Maronite priest claimed that they were never invited, while the leader of the Muslim scouts then claimed that the Maronites received invitations, but never came. He further says that "The Maronites in Nazareth have tendencies like those in Lebanon, meaning that in neither place do the best of feelings exist between the two groups." 39 Some Christians in Nazareth believed that some of the patterns of the good relations are changing due to the Islamic upsurge:

In the past, Muslims thought they needed Christians and, therefore, established good relations with them. But today Muslims feel that they do not need Christians because of the changes and the rise of the power of the Islamic trend. Today, there are deep doubt and concern for our children's future. Nazareth lost its Christian atmosphere and started to transform into a Muslim city like Jenin and Nablus. Also the fast expansion of the city as a

34 Ibid., January 12, 2012.

35 Chad Emmett, Beyond the Basilica :Christians and Muslims in Nazareth. Chicago: University of Chicago Press, 1995, p. 228.

36 Ibid., pp. 225-245.

37 Ibid., p. 228-229.

38 Ibid., p. 226.

39 Ibid., p. 235. 
result of the immigration added to the difficulties of establishing friendly

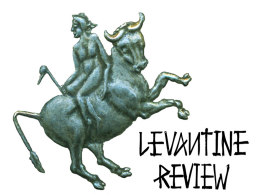
relations. ${ }^{40}$

The common Nazarene culture refers to by Emmett as the "centripetal forces," is challenged by the growing chasm between Christian and Muslim communities, fueled by the "centrifugal forces" of political cleavage and religious difference. He examines the educational, economic, and political factors that enlarged the rift between the two populations. Very few interviewees agreed to discuss with him in detail and depth the problematic relations between the two communities, although many admit that they exist. He writes about and quotes one of his interviewees:

At one time, people didn't think about whether or not you were Christian or Muslim; our nationalistic feelings united us; now, however, the "Muslims are controlling everything," and the Christians are "becoming second-rate citizens"... Muslims controlling all the shops in the market, although the Christians do nothing about it. The Muslims are working on gaining power, and the weak Christians are doing nothing because they are afraid that if they bring up the issue of Muslim dominance, they will break up the ChristianMuslim unity and arouse the temper of the Muslims. ${ }^{41}$

Some of the interviewees claimed that there are many problems between Muslims and Christians in their neighborhood, while others feared to enter the Hara Sharqiyya (The Eastern quarter.) Mundhir Qupti, a Coptic interviewee, explains that the close relationship that his parents had with their Muslim neighbors no longer exists. Today, there is no friendship, just "a hello in passing." The rapid expansion of Nazareth, combined with the influx of many strangers, has made it harder for the two communities to maintain good relations. ${ }^{42}$

Another Emmett interviewee said that Christian political identity is free from any religious identification. However, Muslims identify with religious groups to promote political ideologies. His example is the Islamic party that mixes politics and religion, a combination that goes back to the periods of the Ottoman and British Mandate. With the advent of the Islamic movement in the 1989 local elections, power shifted to the Muslims: 13 of them were elected to city council as opposed to only 6 Christians. According to Mazen Mahzumi, one of the leaders of the Islamic list then, "all the Muslims of Nazareth are Harakat Islamiyya [Islamic movements,]" maybe ninety-eight percent." For Mahzumi, there is no difference between being Muslims and members or supporters of haraka Islamiyya. Even

${ }^{40}$ Siham Fahum Ghneim, Tahadiyyat, Taghayurat wa-Tahawulat fi Tarikh al-Nasira: al'Ilakat al-Islamiyya al-Masihiyya (Challenges, Changes and Shifts in the History of

Nazareth: the Muslim-Christian Relations). Nazareth: Matba'at al-Nasira, 2003, p. 389. 41 Chad Emmett, Beyond the Basilica :Christians and Muslims in Nazareth, p. 249. 42 Ibid., pp. 248-251. 


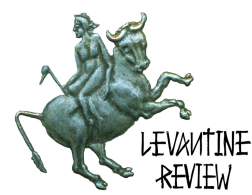

those who identify themselves as "secular Muslims," or non-religious are associated with the Islamic movement just for being Muslims. The 2 percent to which Mahzumi does not refer, Emmett assumes are atheists or communists. ${ }^{43}$

The disparities between the two communities of Nazareth have grown since then. In the last two decades, the face of the city has changed with the rapid increase in the number of Muslims in the entire Nazarene population, and of those who returned to religion. Chief Editor of al-Sunara newspaper, Vida Mashour from Nazareth explains:

In the 1990s, even before, my daughters could wear shorts and go out. Today this is impossible. Today, Nazareth is in retardation. Today, it is impossible to walk in the streets wearing shorts. Today when I walk down the streets, I am surprised to see that $90 \%$ of the [Muslim] girls and women are veiled. ${ }^{4}$

The Islamic upsurge and the rising number of Muslims in Nazareth have widened the cultural cleavage between the two communities. Samer Salman, an accountant and an active member in Nazareth's Latin Church, indicates that the social disparities are evident in weddings during which a non-religious Muslim woman follows the conservative dress code and the religious woman would wear the veil. In contrast, a Christian woman would appear in modern "European-American" style with no regard to Arab conservative traditions:

If my sister wants to go to a Christian wedding, she will wear a dress that fits Christian weddings. But, to a Muslim wedding, she will be cautious and take into consideration the feelings of those who are present. In the opposite situation, if I invite some of them [Muslims], they will not try to dress up any closer to what the Christian guests are wearing. ${ }^{45}$

Salman claims that some Muslim women in Nazareth practice modern life, but many others abstain from socializing with men unless within specific frameworks, charity institutions, and family socialization. Muslim religious women are not seen in restaurants and coffee shops especially at night, and the number of veiled women is constantly rising, some even wear the burqa (A religious Islamic garment that covers the entire face and body of a woman).

In Haifa, an emblem of Christian, Muslim, and Jewish coexistence in Israel, there is an evident interaction between the three groups in some mixed neighborhoods, markets, and places of work. Living along with the secular Jewish majority in the city, Christians are less restricted by the conservative traditions practiced in villages and towns dominated by

43 Ibid., pp. 255, 264.

44 Interview, August 30, 2010

45 Ibid., August 30, 2010 


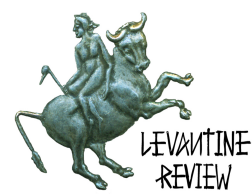

Muslims. And, it is the Muslim society, as a minority within a minority in Haifa that often adopts features of the dominant Christian and Jewish cultures. These differences were already evident in the 1950s. According to Kayed Abboud, a former counselor of the Police Ministry, Christians' social make-up in Haifa was closer to that of the Jews with which some Christian families lived:

So it happened in Wadi al-Nisnas in Haifa that in the same house with an Arab family, Christian or Muslim, mainly Christians, you could find next to the Christian family a Jewish family in the same house, the same entrance, the same kitchen, the same bathroom... Then life changed, and every family wanted to be independent without sharing... Jews [in Haifa] preferred to live with Christians more than with Muslims. I think, this, no doubt, goes back first to the background in the Arab-Islamic and Jewish struggle, and second to the differences in the level of civilization. Meaning, Christian families or the parents, spoke more than one language because of their educational background, in Christian schools. This creates a common language and civilization, and indicates more social openness. ${ }^{46}$

Despite the development of Muslim society in Haifa, the differences in the demographic and cultural features that existed between the two communities remain still. The birth rate of Muslims remains higher than that of Christians. ${ }^{47}$ The culture of the latter is associated more with Western concepts and traditions. Despite the fact that the cultural gap between Christians and Muslims in Haifa is narrower than it is in mixed Christian-Muslim villages and towns, the difference in religious and social practices between the two communities remains clear. According to Amalia Sa'ar, cultural identification with the West is a major constituent of the self-image of Haifa's Christians, and that is apparent in the education system of their private schools to which the majority of Christians send their children. These schools are perceived as conservative, yet they relate to Western culture. Therefore, she claims, Haifa's Christians are still "more cultural" for having more access to the allegedly "higher level" western culture. ${ }^{48}$

Former Knesset member Nadia Hilu indicates changes in Christian-Muslim relations are not uniform. She says that similar to Haifa, the Islamic movement has little influence in her

46 Interview, August 26, 2010.

47 The fertility rate of a Christian woman in 2009 was 2.04, compared to 2.63 for a Muslim woman. See Haifa Municipality, <www.http://www.haifa.muni.il>, "Dimografya" (Demography). $<$ http://www1.haifa.muni.il/spru/doc/YB/Dmgrp/Y2009/Download/DemographyDL.pd $\mathrm{f}>$, November, 2011.

${ }^{48}$ Amalia Sa'ar, "Carefully on the Margins: Christian Palestinians in Haifa between Nation and State", American Ethnologist, vol. 25, no. 2 (1998), p. 8. 


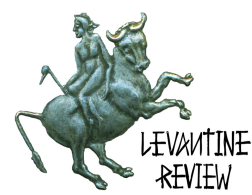

home-town of Jaffa-Tel-Aviv, and that the two communities live peacefully together. This is not the case in other villages and towns where,

Religious Muslims sometimes dictate a certain lifestyle because they will not accept the weddings and the daily life pattern of Christians. Once, there were more connections [between the two communities] in weddings. This [difference in daily life pattern] creates more distance. However, where I live, mutual respect still exists. But, of course, we cannot overlook areas where the distinction between Christians and Muslims created tensions and frictions. It was not only friction but tension and violence. ${ }^{49}$

\section{MUSLIM-CHRISTIAN RIOTS: THE CASE OF NAZARETH}

In Nazareth, Christians constitute a steadily declining minority. Conflicts between Christians and Muslims in Nazareth began in the early 1950s with a skirmish involving Greek Catholic scouts and Muslims. On April 5, 1952, a Muslim boy from Nazareth threw a stone at the scouts from Shafa'amr who arrived to the city to participate in the Sunday mass. The scoutmaster pursued the boy and a fight erupted resulting in the death of an old Muslim man. Although the conflict was under the title "Christians and Muslims clash in Nazareth", an inter-Christian dispute erupted when the Communists accused their opponent Greek Catholic Archbishop Hakim of the incident, and he accused the Communists of attacking the scoutmaster. The conflict ended in a peace agreement between the church scouts and the family of the Muslim man who died. ${ }^{50}$

In another incident in 1989, a 13 years old Christian boy, Salim Nusseri, was found dead. The Muslim suspect was a drug addict named Arab Marhum who robbed the kid. Although the motive was not apparently religious, it inflamed tension between the two communities. ${ }^{51}$

Such incidents revealed an increase in tension, suspicion, and mistrust between Christians and Muslims in mixed villages and towns. It began as a non-religious feud and degenerated into violent Muslim-Christian conflict. Whenever a riot erupts between the two communities, Christians are the weaker side that suffers more damage and injuries. Latin Patriarch Michel Sabbah says:

Generally, yes, the Christian is the weaker. This is obvious. This is clear because of the number [of Christians], and probably because of their manners that do not allow them to kill and to turn to violence... Being a minority, the Christian is the victim. What happened to Christians in Iraq? All Christians paid the price because they are the weaker, and the number of their men is

49 Interview, December 13, 2010.

50 Chad Emmett, Beyond the Basilica :Christians and Muslims in Nazareth, p. 252.

51 Ibid., p. 252-253. 
less than those of others [Muslims]. They are not in millions and are not

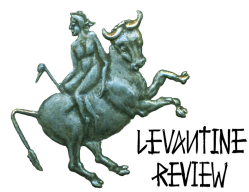
armed. .5

The conflict between Christians and Muslims in Israel reached its zenith in the years 19972003, in a dispute between the Islamic movement and the municipality (headed by Greek Orthodox Ramez Jarraysi) of Nazareth over plans to build a mosque that will overshadow the Church of Annunciation. According to the Christian belief, this Church was the place where the angel Gabriel announced to the Virgin Mary that she would conceive from the Holy Spirit, and become, according to the Christian belief, the mother of God.

The land was allotted to the municipality of Nazareth by the Labor Prime Minister Yitzhak Rabin to build a park in preparation for the 2000 celebrations in Nazareth (Nazareth 2000.) The construction included the renovation of the tomb of Shihab al-Din, located near the church. Shihab al-din was the nephew of Salah al-Din, the Muslim commander who defeated the Crusaders. The head of the local Islamic Waqf (Endowments), Abu Nawaf, demanded that the municipality construct a mosque on the plot, and this precipitated the rift between the two communities. On December 21, 1997, together with hundreds of Muslims Abu Nawaf invaded the plot to protest the resistance of the Municipality of Nazareth, and of Christians, and some Muslims towards building the Mosque. He claimed that the square was an Islamic mosque. This was amidst preparations for the celebrations of 2000, which emphasized the significant Christian character of the city. ${ }^{53}$

In April 1999 clashes erupted between Muslims and Christians over the issue. The riots broke out in Nazareth during the Christian Easter celebration between the members of the Islamic movement and its supporters, and some Christians. The clashes accelerated as they attacked Christians in the streets as well as Muslims known as "collaborators." Vida Mashour, said of the violence as she witnessed it:

We wrote about our offices [in al-Sunara newspaper] that they [the Muslims] have stoned. One day we were driving to the offices to see what happened. We wanted to walk in the streets, and they [some Muslims] saw that we were women and were about to attack and stone us, I told my daughter to "turn around right away".54

Or as accountant Samer Salman recollects:

52 Interview, December 22, 2010.

53 Daphne Tsimhoni, "The Christians in Israel: Aspects of Integration and the Search for Identity of a Minority within a Minority", ", in Moshe Ma'oz and Gabriel Sheffer. Eds. Middle Eastern Minorities and Diasporas, Brighton and Portland: Sussex Academic Press, 2002, pp. 136-7.

54 Interview, August 30, 2010. 
When the feud of the Shihab al-Din took place, many cars and Christian

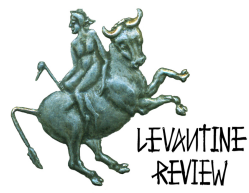
properties were vandalized. When the glass of my car broke, I became less secure and trusting of those who surround me, especially the religious [Muslims]. We should mention that we had very good old relations with our Muslim customers, acquaintances from the 1980s, but we did not develop new relations in the offices with Muslims after 1998. The number of the Muslim customers between the years 1998 and 2010 does not exceed five. ${ }^{55}$

The Israeli government ordered the police force not to intervene in the clashes. The government's indifference to the violent events came at the hope of securing more votes for the nearest election by siding with the Islamic movement. The Ben Ami ${ }^{56}$ committee, called by Benjamin Netanyahu's government, concluded that the intruders' rights should be recognized. This seemed an obvious attempt to bribe the Muslim community and win their voters. ${ }^{57}$

When Ben Ami was asked about the failure of the police to protect Christians on their way to the Church of the Annunciation, he replied that he was not in the mood to discuss such "trivial" issues. ${ }^{58}$ For hours, the police did not stop the attacks. In an interview with the Northern District police commander, Alik Ron, he indicated that the police's initial lack of interference was an order from above. ${ }^{59}$ Mansour criticized Ron for failing to protect Christians in Nazareth during the 1999 events of Shihab al-Din. By comparison, in the year 2000, 13 young Arab Muslims were killed during their demonstrations against the government. Alik confronted the demonstrators not only with tear gas and rubber bullets, but also with special anti-terror special snipers. Prime Minister Barak was forced to set up a judicial committee headed by a chief justice to investigate the police and their harsh treatment of the Arab citizens".60

In a letter from the Latin, Orthodox and Armenian Patriarchs, and the Custodian of the Holy Land addressed to all ambassadors, local Christians, Christian pilgrims, and travel agents in the Holy Land, they declared that "all the Sanctuaries of the Holy Land will be closed on 22 and 23 November 1999," a protest to the Shihab al-Din events, and to "the Israeli Ministerial decision to give the go-ahead for the laying of the cornerstone to this construction on 8 November 1999." They claimed that the Israeli government has

55 Interview, August 30, 2010

56 Ben Ami was the Minister of Internal Security.

57 Atallah Mansour, Narrow Gate Churches. California: Hope Publishing House, 2004. p.282.

58 Ibid., p. 282.

${ }^{59}$ Daphne Tsimhoni, "The Christians in Israel: Aspects of Integration and the Search for Identity of a Minority within a Minority", p. 137.

60 Atallah Mansour, Narrow Gate Churches, p. 283. 


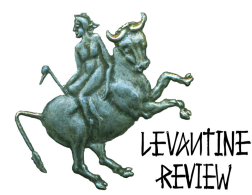

supported the fundamentalists in order to create tension among Christians and Muslims in Israel and to promote electoral interests. ${ }^{61}$

In November 1999, the Executive Committee of the Orthodox Conference in Israel condemned Israel for abandoning the Christians and the Muslims who denounced the violence perpetuated against Christians: ${ }^{62}$

We accuse the [Israeli] police for failing in its duty by watching the physical violence, provocations and incitement that Christians and others had to endure. We also salute those who were attacked that showed a good discipline and did not follow the politics [of Israel] of "divide and rule" [between Christians and Muslims]. They do that not out of weakness, but to avoid sliding into a worse danger. At the same time, we should blame our Muslim brothers who despite our full confidence that they were against the mounting violence and the confrontation, did not condemn these acts.

The proclamation further delineates the position of Christians to building the mosque:

No one should accuse the Christians, as the media did, of being opponents of building the mosque or any Muslim worship houses. During the last 30 years, and with no one's objection, more than 15 mosques were built in Nazareth some of which are adjacent to Christian churches. Christian opposing position was mistaken. It resulted from the challenging and inciting approach that stirred up their religious sentiments, and from the attacks against them together with the sensitivity of the location.

In a TV interview on Friday April 9, 1999 with Moshe Katsav, minister of tourism and in charge of Arab affairs in Netanyahu's government then, he declared his support of the Islamic movement and the plans to build the mosque. The local leader of the movement, Salman Abu Ahmad, complemented Katsav on his declaration and said that his party had not decided who it will endorse in the elections (Netanyahu or Barak.) ${ }^{63}$ Ahmad's praises of the Israeli government's support came after making an evident threat against opponents of building the mosque: "The hand of those who will bargain on Muslim properties will be decapitated," and Sheikh Abdel Salam Manasra said: "If the Israel Lands Administration will reclaim the location [where the mosque was supposed to be built,] we will turn the struggle between us and her." ${ }^{4}$ Both the Netanyahu and Barak governments supported the

61 Fuad Farah, Israeli Christian author, Private Collection

62 Ibid., Private Collection.

63 Daphne Tsimhoni, "The Christians in Israel: Aspects of Integration and the Search for Identity of a Minority within a Minority", p. 137.

64 Al-Sunara, December 24, 1997. 
movement by offering solutions to build the mosque on part of the allotted land, and allotting more lands in Nazareth for religious purposes of the movement. ${ }^{65}$

The cooperation between the Government and the movement has been perceived by some commentators as an attempt to damage the "Arab national image" as it confirms the representations of groups by religious circles rather than national ones: the support of the Israeli Jewish government of building a mosque adjacent to the Annunciation Church would lead to a direct intervention by the church and its affiliates. Thus, the church would allegedly become the major representative of the Christian community. It would further increase their sense of belonging to a Christian identity rather than to the Arab national identity, which they allegedly enjoyed prior to the Israeli Islamic religious awakening. It would be undermined by the empowerment of the Christian religious leaders. Accordingly, Israel's policy is negatively perceived by those who claim that it plots to break the national unity between Christians and Muslims by characterizing the struggle between them as religious. ${ }^{66}$

In November 1999, the Islamic Waqf set the cornerstone of the mosque. But, when prime minister Ariel Sharon visited the White House in March 2001, President George Bush appealed to him to prevent the building of the mosque. The Waqf began construction in the controversial location, but the court ordered a halt to the building. The Vatican pressured the Israeli government to cancel its approval of the building, and finally in 2002 the government ordered the construction to cease. ${ }^{67}$ Christians welcomed the decision and Father Raed Abu Sakhliyya, Secretary of the Latin Patriarch in Jerusalem, said that "the decision of the government is positive and we hope that it will keep its promise of halting the construction." He also expressed his hope that the government would find a final solution to this problem because Christians are not opposed to building the mosque but to its sensitive location. ${ }^{68}$

Despite the perceived disregard of Christians by the state, Father Emil Shoufani emphasized the significance of Israeli citizenship. He claimed that the Islamic movement is weakening and no longer constitutes the perceived threat:

Inside the country [Israel], we have opportunities of dialogue with the government and with the Israeli institutions through something we all

65 For more information on the solutions and deals offered for the benefit of the Islamic movement see Daphne Tsimhoni, "The Christians in Israel: Aspects of Integration and the Search for Identity of a Minority within a Minority", pp. 137-142.

66 Al-Ittihad, "Shihab al-Din, Jerusalem and the Permanent Solution", 2000.

67 Haaret, "Beit ha-Mishpat Hora la-Waqf be-Natsrat le-Hafsik et 'Avodot ha-Bniyya" (The Court ordered the [Islamic] Waqf in Nazareth to Halt the Constructions), March 2003.

${ }^{68}$ Al-Dustour (The Constitution), "Israil Tuwaqef Binaa Masjid Shihab al-Din" (Israel Halts the Construction of Shihab al-Din), January, 2002. 
understand; we are all citizens. The awareness that you are a citizen inside the country and the country of Israel is very important in every dialogue with the Jew. The Islamic movement is a total failure. It has finished what it came to do. I see them disagree, some are in the Knesset and some are not. This does not frighten me. During Shihab al-Din's incidents, I never agreed with those [some Christians] who wanted several times to cancel the entrance of the Patriarch [to the city of Nazareth], and the Christmas March. We shall march and pass through and let them [the Muslims] come and shake our hands and serve us sweets. Some will also toss stones, let it happen, what can I do to them? ${ }^{69}$

The cultural gap between Christians and Muslims has widened in the last four decades due to the strengthening of the Islamic religious identity. With the decline of Arab identity and the national character to which Christians have belonged, and with the increase in the number of religious Israeli Muslims, the internal social division between the two groups, mainly in mixed villages and towns with a Muslim majority, has become more obvious. The national character under which the supposedly "vast Christian-Muslim family" lived has been diluted and surpassed by the religious character.

The clashes between Muslims, mainly the Islamic movement and its supporters, and Christians in Nazareth at the end of the 1990s and the beginning of 2000, is indicative of the weakened position of Christians as a minority within a minority in Israel. Christians claimed that they were not receiving the necessary protection from the state when they were attacked. They said that the Israeli government was supporting the Islamic movement's position and was siding with the Muslims, the largest majority in Israel.

* Rima Farah is a graduate student in the department of Near Eastern and Judaic Studies at Brandeis University. Her research deals with the history and memory of Near Eastern Christians, with a special focus on the Maronite communities of Israel and Lebanon.

${ }^{69}$ Interview, September 1, 2010. 